\title{
Analisis Kesuksesan Sistem Informasi Manajemen Puskesmas pada Pengelolaan Obat di Puskesmas Kabupaten Batang
}

\author{
Analysis of Implementation of Information System on Drug Management in Community Health Centres \\ in Batang District
}

Rizza Fauziyah ${ }^{1 *}$, Satibi $^{2}$, Eko Nugroho ${ }^{3}$

1. Magister Manajemen Farmasi, Fakultas Farmasi, Universitas Gadjah Mada

2. Fakultas Farmasi, Universitas Gadjah Mada

3. Minat Studi Manajemen Informasi dan Perpustakaan, Sekolah Pascasarjana, Universitas Gadjah Mada Submitted: 13-03-2019 Revised: 22-05-2019 Accepted: 02-06-2019

Korespondensi : Rizza Fauziyah : Email : rizzayankes@gmail.com

\section{ABSTRAK}

Puskesmas di seluruh wilayah Kabupaten Batang telah mengimplementasikan Sistem Informasi Manajemen Puskesmas (SIMPUS) pengelolaan obat sejak tahun 2010 untuk mempercepat akses data obat, mempercepat dan meningkatkan akurasi pelayanan resep, serta memberikan informasi yang akurat dan tepat waktu untuk mendukung proses perencanaan, pengadaan, dan distribusi. Penelitian ini bertujuan untuk menganalisis tingkat kesuksesan pemanfaatan sistem informasi manajemen pengelolaan obat di puskesmas Kabupaten Batang ditinjau dari persepsi pengguna. Penelitian ini bersifat deskriptif analitik kuantitatif. Data dari 29 responden dikumpulkan menggunakan survei kuesioner yang dikembangkan dari model kesuksesan Delone dan McLean yang diperbaharui. Analisis kuantitatif kuesioner menggunakan skala sikap "Likert". Uji hipotesis dilakukan untuk mengetahui bagaimana hubungan dan pengaruh antarvariabel dengan analisis Structural Equation Modelling Partial Least Square (SEM-PLS). Pengujian hipotesis menggunakan probabilitas dua arah dengan tingkat signifikansi $(\alpha) 5 \%$ dimana nilai T-statistik lebih dari 1,96 bermakna bahwa terdapat pengaruh yang signifikan antarvariabel. Hasil penelitian menunjukkan bahwa variabel kualitas sistem terhadap penggunaan sistem, kualitas sistem terhadap kepuasan pengguna, serta kualitas layanan terhadap kepuasan pengguna berpengaruh secara positif dan tidak signifikan. Hubungan variabel penggunaan sistem terhadap kepuasan pengguna berpengaruh secara negatif dan tidak signifikan. Sedangkan hubungan variabel kualitas informasi terhadap penggunaan sistem, kualitas informasi terhadap kepuasan pengguna, kualitas layanan terhadap penggunaan sistem, penggunaan sistem terhadap net benefit, serta kepuasan pengguna terhadap net benefit berpengaruh secara positif dan signifikan. Dapat dinyatakan kesuksesan pemanfaatan SIMPUS pada pengelolaan obat di puskesmas Kabupaten Batang secara keseluruhan belum optimal, diperlukan perbaikkan pada kehandalan dan efektifitas sistem dan kualitas layanan untuk meningkatkan tingkat pemanfaatannya.

Kata kunci: SIMPUS; Pengelolaan Obat; Net Benefit

\begin{abstract}
Every Public Health Center in all regions of Batang Regency has implemented a Public Health Center Management Information Systems (SIMPUS) in drug management since 2010 to accelerate access to the drug data, accelerate and improve the accuracy of prescription services, as well as provide accurate and timely information to support the planning, supply, and distribution processes. This study aims to analyze the level of success in the use of information management systems for drug management in the Batang District public health center in terms of user perceptions. This research is a descriptive quantitative analytic. The data from 29 respondents were collected using a questionnaire survey developed from the updated Delone and McLean success model. The quantitative analysis of the questionnaire uses a "Likert" attitude scale. Hypothesis testing is done to find out how the relationship and influence between variables using Structural Equation Modeling Partial Least Square (SEM-PLS) analysis. Hypothesis testing used twoway probability with a significance level $(\alpha)$ of $5 \%$, whereas the T-statistic value is more than 1.96 , which means there is a significant influence between variables. The results showed that the relationship of system quality variable on system use, system quality on user satisfaction, and service quality on user satisfaction has a positive but not significant effect. The relationship of system use variables to user satisfaction has a negative and not significant effect. While the relationship between variable information
\end{abstract}


quality on system use, information quality on user satisfaction, service quality on system use, system use on net benefit, and user satisfaction on net benefit has a positive and significant effect. It can be stated that the success of SIMPUS utilization as a whole in drug management in the Batang District Public Health Center is not optimal, it needs an improvement on the reliability and effectiveness of the system and the service quality to increase the level of utilization.

Keywords : SIMPUS; Drug Management; Net Benefit

\section{PENDAHULUAN}

Data WHO menyebutkan jumlah penderita diabetes meningkat dari 108 juta penderita pada tahun 1980 menjadi 422 juta penderita pada tahun $2014^{1}$. Indonesia berada pada peringkat ke-6 dalam hal prevalensi diabetes pada usia 20-79 tahun setelah Cina, India, Amerika Serikat, Brazil, dan Meksiko ${ }^{2}$. Pada tahun 2018, prevalensi diabetes berdasarkan diagnosis dokter secara keseluruhan di Indonesia adalah sebesar $2,0 \%$ dengan prevalensi pada provinsi DI Yogyakarta lebih tinggi dibandingkan secara keseluruhan di Indonesia dan menempati peringkat ketiga setelah DKI Jakarta dan Kalimantan Timur ${ }^{3}$.

Diabetes mellitus (DM) merupakan penyakit metabolik kronik dan progresif yang menyebabkan berbagai macam komplikasi sehingga dapat meningkatkan angka kematian pasien. World Health Organization melaporkan pada tahun 2012 terdapat 1,2 juta angka kematian pasien akibat diabetes mellitus ${ }^{1}$. Diabetes mellitus juga berdampak pada beban ekonomi yang mencakup biaya langsung untuk mengobati diabetes dan komplikasinya, biaya kehilangan produktivitas akibat diabetes dan komplikasinya, serta biaya akibat adanya disabilitas yang berhubungan dengan diabetes 4,5 .

Pasien diabetes tipe 2 menerima berbagai macam terapi karena adanya komorbid sehingga seringkali berisiko tinggi mengalami Drug-Related Problems (DRPs) ${ }^{6}$. Beberapa studi mengenai DRPs telah dilakukan. Sebuah studi di New South Wales menunjukkan bahwa terdapat 682 DRPs yang mana pasien mengalami setidaknya satu DRPs dengan rerata 4,6 $\pm 1,7$ DRPs per pasien dengan mayoritas DRPs terjadi sebanyak 264 kasus dalam hal kegagalan terapi dan sebanyak 206 kasus dalam hal kesalahan pemilihan obat ${ }^{7}$. Studi serupa juga telah dilakukan pada pasien rawat inap usia lanjut dengan diabetes tipe 2 dan hasil menunjukkan bahwa rerata DRPs per pasien adalah 2,96 $\pm 2,2$ dengan proporsi kasus tiap kategori DRPs yaitu $6,05 \%$ dalam hal obat tanpa indikasi; $7,15 \%$ indikasi tanpa obat; $3,85 \%$ obat tidak tepat; $0,55 \%$ dosis obat terlalu tinggi; $0,85 \%$ adanya toksisitas obat; $1,92 \%$ duplikasi terapi; $2,75 \%$ efek samping obat; $40,93 \%$ interaksi obat; dan 35,71\% ketidaksesuaian pengobatan pada usia lanjut menurut acuan Beers Criteria 8 .

Studi terdahulu telah menghubungkan antara DRPs dengan pengendalian gula darah 9 serta morbiditas dan mortalitas pasien diabetes tipe $2{ }^{10}$, tetapi sepanjang pencarian literatur oleh penulis, belum ada suatu studi yang menghubungkan antara Length of Stay (LOS) dengan DRPs pada pasien diabetes tipe 2. Studi yang telah dilakukan adalah menghubungkan antara LOS dengan Medication Error (ME). Peneliti menyebutkan bahwa ME termasuk DRPs karena error juga merupakan suatu masalah ${ }^{11}$ dan hasil studi tersebut menunjukkan bahwa ME berhubungan dengan peningkatan LOS 12-14. Oleh karena itu, maka penelitian ini bertujuan untuk mencoba mengidentifikasi DRPs pada pasien diabetes tipe 2 di rumah sakit dan menghubungkannya dengan LOS.

\section{METODE}

\section{Rancangan Penelitian}

Penelitian ini merupakan studi observasi prospektif dengan rancangan cross sectional. Pengumpulan sampel dilakukan dengan metode sampling secara konsekutif terhadap pasien diabetes tipe 2 rawat inap di bangsal penyakit dalam salah satu rumah sakit akademik di Yogyakarta. Analisis data dilakukan secara deskriptif untuk melihat gambaran drug-related problems pada pasien diabetes tipe 2 rawat inap di rumah sakit 
tempat penelitian. Pengambilan data dilakukan pada bulan Januari s.d. April 2018.

\section{Populasi dan Sampel Penelitian}

Populasi penelitian ini adalah semua kasus pasien diabetes tipe 2 rawat inap di rumah sakit tempat penelitian selama bulan Januari s.d April 2018. Sampel penelitian ini adalah semua kasus pasien diabetes tipe 2 rawat inap di rumah sakit tempat penelitian yang berusia $\geq 18$ tahun dan memiliki penyakit penyerta selama bulan Januari s.d April 2018. Kriteria eksklusi penelitian adalah kasus pasien yang dirawat inap lebih dari sekali selama periode penelitian. Peneliti menggunakan data terakhir (terbaru) dari suatu kasus pasien apabila pasien tersebut masuk rumah sakit lebih dari satu kali selama periode pengambilan data.

Penentuan besar jumlah sampel dilakukan dengan menggunakan rumus besar sampel ${ }^{15}$.

$$
\mathrm{n}=\frac{\mathrm{Z}_{1-\mathrm{a} / 2}{ }^{2} \mathrm{P}(1-\mathrm{P})}{\mathrm{d}^{2}}
$$

dengan nilai $\mathrm{P}$ (proporsi DRPs secara umum hasil studi pendahuluan menggunakan 20 pasien pertama) dan d (presisi) yang ditetapkan masing-masing 0,85 dan 0,1; maka jumlah minimal sampel yang diperlukan adalah 49. Rumus besar sampel yang digunakan pada penelitian ini tidak menggunakan data populasi karena penelitian ini dilakukan secara prospektif dan populasi pasien yang masuk rumah sakit untuk dirawat inap tidak diketahui.

\section{Asesmen DRPs}

Pada penelitian ini DRPs dikategori menjadi: 1) terapi obat yang tidak diperlukan, 2) membutuhkan tambahan terapi obat, 3) obat tidak efektif, 4) dosis obat terlalu rendah, 5) efek samping obat, dan 6) dosis obat terlalu tinggi ${ }^{16}$. Kategori kepatuhan tidak diidentifikasi dalam penelitian ini karena subjek dalam penelitian ini adalah pasien rawat inap yang penggunaan obatnya diberikan langsung oleh perawat sehingga risiko ketidakpatuhan pasien sangat rendah.

Kategori terapi obat yang tidak diperlukan yaitu apabila pasien menerima terapi obat yang tidak sesuai dengan kondisi pasien selama di rawat inap. Kategori ini meliputi terapi tanpa indikasi yang jelas, pasien menerima kombinasi obat yang sebenarnya cukup dengan obat tunggal dan terapi dengan tujuan untuk mencegah efek samping obat lain.

Kategori membutuhkan tambahan terapi obat yaitu apabila berdasarkan diagnosis, anamnesis, atau hasil laboratorium terdapat kondisi atau gejala klinik pasien yang seharusnya mendapatkan pengobatan, tetapi belum diberikan pengobatan selama pasien di rawat inap. Kategori membutuhkan terapi obat tambahan juga termasuk apabila obat tambahan diperlukan dalam rangka mencapai efek sinergistik ketika pasien belum juga mencapai target terapi padahal pasien telah diberikan pengobatan lini pertama berdasarkan pedoman terapi. Oleh karena itu penambahan obat lini kedua dan atau ketiga dibutuhkan untuk mencapai target terapi melalui efek sinergistik.

Kategori obat tidak efektif meliputi kejadian obat bukan merupakan obat yang paling efektif untuk pasien, kondisi medik pasien sulit disembuhkan dengan obat yang sudah diberikan, dan adanya kontraindikasi obat. Pasien dikategorikan menerima obat bukan merupakan obat paling efektif untuk pasien apabila suatu indikasi pada pasien diberi terapi obat pilihan pertama dengan dosis maksimal, tetapi target terapi belum tercapai atau suatu indikasi diberi obat bukan obat pilihan pertama sehingga target terapi belum tercapai.

Kategori dosis obat terlalu rendah meliputi kejadian dosis obat terlalu rendah untuk menghasilkan respon yang dikehendaki, frekuensi pemberian obat terlalu jarang, dan durasi pengobatan terlalu pendek. Kategori efek samping obat meliputi kejadian terapi obat yang menyebabkan efek yang tidak diharapkan dan perlunya obat yang lebih aman karena adanya faktor risiko. Kategori dosis obat terlalu tinggi meliputi kejadian dosis obat yang terlalu tinggi, frekuensi pemberian obat terlalu sering, durasi pemberian obat terlalu 
panjang, dan dosis obat dinaikkan terlalu cepat.

Semua kategorisasi DRPs tersebut berdasarkan penilaian terhadap data subjektif dan objektif pasien. Data subjektif yang dimaksud adalah keluhan pasien yang didapat dari rekam medik dan wawancara terhadap pasien setiap hari, sedangkan data objektif yang dimaksud meliputi hasil pemeriksaan laboratorium pasien dan diagnosis dokter.

\section{Jalannya Penelitian}

Pasien diabetes tipe 2 rawat inap dikumpulkan menggunakan metode sampling secara konsekutif. Lembar informed consent digunakan sebagai bukti kesediaan pasien dalam mengikuti penelitian ini. Apabila setuju untuk ikut dalam penelitian ini, pasien menandatangani informed consent. Setelah pasien menyetujui untuk ikut dalam penelitian ini, maka riwayat pengobatan dan perkembangan pasien dipantau setiap hari untuk mengetahui ada tidaknya drug-related problems dalam pengobatan pasien.

Perkembangan yang diamati meliputi perkembangan data subjektif dan objektif pasien, kadar glukosa darah, dan kemungkinan efek samping obat. Pedoman manajemen diabetes yang digunakan adalah American Diabetes Association (ADA) tahun 2017 dan buku Drug Information Handbook tahun 2011 digunakan sebagai rujukan dalam melihat dosis, pemilihan obat yang tepat, dan efek samping obat. Pada akhir tahap pengumpulan data, DRPs yang telah diidentifikasi didiskusikan dengan dokter yang merawat pasien melalui persentasi hasil penelitian. Drug-related problems pada pasien dijabarkan secara deskriptif.

\section{Analisis Data}

Data yang diperoleh dari rumah sakit dianalisis secara deskriptif dalam hal karakteristik pasien dan perhitungan kasus DRPs serta proporsi tiap kategori. Data karakteristik pasien yang bersifat kategorik diolah dalam bentuk proporsi, sedangkan data yang bersifat numerik diolah dalam bentuk desimal. Kedua jenis data karakteristik disajikan dalam bentuk tabel. Gambaran drug- related problems dalam penelitian diketahui dengan menghitung jumlah keseluruhan DRPs pasien, proporsi pasien yang mengalami DRPs, rerata DRPs per pasien, serta proporsi DRPs tiap kategori dan penyebabnya. Proporsi pasien yang mengalami drug-related problems dihitung dengan membagi banyaknya pasien yang mengalami DRPs dengan jumlah total pasien dalam hitungan persen. Proporsi kategori DRPs dihitung dengan membagi banyaknya kasus DRPs tiap kategori dengan total kasus DRPs dalam hitungan persen. Proporsi penyebab DRPs tiap kategori dihitung dengan membagi banyaknya kasus penyebab tersebut dengan total kasus DRPs tiap kategori dalam hitunga persen. Rerata banyaknya DRPs yang dialami tiap pasien diabetes tipe 2 rawat inap dihitung dengan membagi keseluruhan jumlah DRPs dengan total pasien. Hubungan antara DRPs dengan LOS dianalisis menggunakan uji Chi-square atau Fisher's exact test sebagai metode uji alternatif apabila syarat uji Chisquare tidak terpenuhi dan Odds Rasio (OR) digunakan untuk mengetahui kekuatan hubungan di antaranya. Nilai p <0,05 menandakan bahwa terdapat suatu hubungan antara DRPs dan LOS. Nilai OR $<1,00$ menandakan bahwa DRPs menurunkan kemungkinan terjadinya LOS $\geq 5$ hari, nilai $\mathrm{OR}=1,00$ menandakan bahwa tidak ada hubungan antara DRPs dengan kemungkinan terjadinya LOS $\geq 5$ hari, sedangkan nilai OR $>1,00$ menandakan bahwa DRPs meningkatkan kemungkinan terjadinya LOS $\geq 5$ hari.

\section{HASIL DAN PEMBAHASAN}

Proses pengumpulan subjek penelitian pasien diabetes tipe 2 rawat inap di salah satu rumah sakit akademik di Yogyakarta dilakukan dengan metode sampling secara konsekutif. Hasil studi pendahuluan dari 20 pasien pertama menunjukkan bahwa $85 \%$ pasien mengalami DRPs sehingga besar subjek dalam penelitian adalah sebanyak 49 kasus pasien.

Total kasus pasien diabetes tipe 2 rawat inap yang masuk selama periode minggu kedua bulan Januari hingga minggu kedua 
bulan April sebanyak 38 kasus pasien. Keseluruhan pasien memenuhi kriteria inklusi, tetapi data yang diambil adalah data rawat inap terbaru apabila pasien dirawat lebih dari sekali sehingga total pasien yang menjadi subjek penelitian adalah sebanyak 36 kasus pasien. Namun demikian, penelitian ini hanya berhasil mendapat 36 kasus pasien selama tiga bulan periode penelitian. Oleh karena itu, apabila tingkat presisi aktual hasil penelitian dihitung menggunakan rumus:

$$
d^{2}=\frac{\left(Z_{1-\alpha / 2}\right)^{2}(P)(1-P)}{n}
$$

dengan $\mathrm{n}$ (jumlah subjek yang berhasil didapat) 36, maka tingkat presisi aktual hasil penelitian ini adalah sebesar $12 \%$. Besar sampel kurang representatif karena jumlah pasien DM tipe 2 dalam penelitian ini sangat sedikit meskipun penelitian telah dilakukan selama empat bulan. Peneliti menemukan bahwa studi lain dilaksanakan dalam periode rawat inap enam bulan, tetapi studi tersebut dilakukan secara retrospektif ${ }^{6}$. Tidak ada studi mengenai DRPs yang dilakukan secara prospektif sampai lebih dari empat bulan 8,11,17 yang berhasil ditemukan oleh penulis sehingga penulis menilai bahwa memperpanjang durasi penelitian tidak akan menambah jumlah sampel dan mengubah hasil secara signifikan.

\section{Deskripsi Karakteristik Sampel Penelitian}

Pasien dalam penelitian ini adalah semua pasien diabetes tipe 2 di rumah sakit tempat penelitian yang memenuhi kriteria inklusi serta tidak termasuk dalam kriteria eksklusi selama bulan Januari hingga April 2018. Jumlah total kasus adalah 38 kasus, tetapi yang terhitung hanya 36 kasus. Gambaran distribusi pasien dapat dilihat dalam Tabel I. Karaktersitik pasien pada penelitian ini umumnya merupakan pasien berusia 45-64 tahun dengan rerata usia 56,19 \pm 8,68 tahun, berjenis kelamin perempuan $(66,67 \%)$, tidak merokok $(86,11 \%)$, dengan penyakit penyerta hipertensi $(19,32 \%)$, gangguan elektrolit $(9,09 \%)$, stroke $(9,09 \%)$, dan dislipidemia (6,82\%).
Hasil penelitian sama dengan penelitian sebelumnya melalui studi cross-sectional pada 48 pasien yang memiliki diagnosis diabetes tipe 2, menyebutkan bahwa penderita diabetes tipe 2 banyak terjadi pada wanita dibanding laki-laki ${ }^{18}$. Sebuah studi prospektif yang menganalisis drug related problems pada pasien diabetes tipe 2 dengan hipertensi di Cimahi, Jawa Barat menyebutkan dari 90 pasien yang diteliti, sebanyak 74 pasien $(82,8 \%)$ adalah wanita ${ }^{17}$. Pasien pada penelitian ini cenderung memiliki penyakit penyerta hipertensi yang mana hal tersebut seperti hasil studi retrospektif terdahulu melalui data rekam medik selama Juli 2014 s.d. Juni 2015 yang hasilnya menunjukkan bahwa sebanyak 64 pasien $(82,1 \%)$ pasien diabetes tipe 2 memiliki penyakit penyerta hipertensi 19 .

\section{Drug-Related Problems}

Hasil penelitian menunjukkan bahwa, 29 pasien dari 36 pasien $(80,56 \%)$ yang bersedia ikut dalam penelitian ini mengalami drug-related problems. Hasil penelitian menunjukkan jumlah drug-related problems yang terjadi sebanyak 72 DRPs, dengan rerata $2,00 \pm 1,67$ DRPs per pasien. Tabel II menunjukkan proporsi pasien diabetes tipe 2 yang mengalami drug-related problems di rumah sakit tempat penelitian. Golongan obat yang berhubungan dengan DRPs dapat dilihat pada Tabel IV. Obat yang paling sering yang menjadi masalah pada penelitian ini adalah antibiotik seftriakson, diikuti oleh obat golongan antidiabetes.

Gambaran DRPs hasil penelitian ini berbeda dengan studi lainnya. Pada penelitian ini DRPs yang paling umum terjadi adalah terapi obat yang tidak diperlukan $(47,22 \%)$, sedangkan DRP yang paling jarang terjadi adalah efek samping obat (5,56\%). Terapi obat yang tidak diperlukan tidak menjadi DRP yang paling umum terjadi pada studi yang dilakukan oleh Ogbonna et al. (2014), van Roozendal et al. (2009), dan Pfister et al. (2017). Namun demikian, pada penelitian yang dilakukan oleh Ogbonna, terapi obat yang tidak diperlukan menduduki peringkat kedua 
Tabel I. Karakteristik Subjek

\begin{tabular}{|c|c|}
\hline Karakteristik & $\begin{array}{c}\text { Proporsi } \\
\text { n (\%) } \\
(\mathrm{N}=36)\end{array}$ \\
\hline \multicolumn{2}{|l|}{ Usia (tahun) } \\
\hline $18-24$ & $0(0,00)$ \\
\hline $25-34$ & $1(2,77)$ \\
\hline $35-44$ & $3(8,33)$ \\
\hline $45-54$ & $12(33,33)$ \\
\hline $55-64$ & $13(36,11)$ \\
\hline$\geq 65$ & $7(19,44)$ \\
\hline \multicolumn{2}{|c|}{ Lama Rawat Inap (hari) } \\
\hline$<5$ & $17(47,22)$ \\
\hline$\geq 5$ hari & $19(52,77)$ \\
\hline \multicolumn{2}{|l|}{ Jenis Kelamin } \\
\hline Perempuan & $24(66,67)$ \\
\hline Laki-laki & $12(33,33)$ \\
\hline \multicolumn{2}{|l|}{ Status Merokok } \\
\hline Ya & $5(13,89)$ \\
\hline Tidak & $31(86,11)$ \\
\hline \multicolumn{2}{|c|}{ Penyakit penyerta* } \\
\hline Hipertensi & $17(19,32)$ \\
\hline \multicolumn{2}{|c|}{ Gangguan keseimbangan elektrolit } \\
\hline Hiponatremia & $5(5,68)$ \\
\hline Hipokalemia & $3(3,41)$ \\
\hline Stroke & $8(9,09)$ \\
\hline Dislipidemia & $6(6,82)$ \\
\hline \multicolumn{2}{|c|}{ Gangguan gastrointestinal } \\
\hline Dispepsia & $4(4,55)$ \\
\hline Vomitus & $2(2,27)$ \\
\hline Diare cair akut & $2(2,27)$ \\
\hline \multicolumn{2}{|c|}{ Gangguan Kardiovaskular } \\
\hline IHD & $3(3,41)$ \\
\hline Heart failure & $1(1,14)$ \\
\hline Ulkus diabetik & $3(3,41)$ \\
\hline Lain-lain & $34(38,64)$ \\
\hline
\end{tabular}

*satu pasien dapat memiliki lebih dari satu penyakit penyerta

tertinggi $(22,8 \%) \quad 6$ dan peringkat ketiga tertinggi $(38,57 \%)$ pada penelitian Pfister ${ }^{11}$. Uniknya, DRP tersebut justru menjadi DRP yang paling jarang terjadi $(0,1 \%)$ pada penelitian van Roozendal dalam bentuk duplikasi terapi ${ }^{7}$. Masalah efek samping obat pada hasil penelitian ini berbeda dengan hasil studi Inamdar et al. (2018) yang mana pada studi tersebut masalah risiko efek samping obat pada lansia yang dinilai berdasarkan $B E E R$ 's criteria justru menjadi DRP dengan peringkat kedua tertinggi $(35,71 \%)^{8}$. Pada studi yang dilakukan oleh Zazuli et al. (2017), DRP yang paling umum terjadi adalah memerlukan tambahan terapi obat $(25,3 \%){ }^{17}$, tetapi pada penelitian ini, memerlukan tambahan terapi obat menjadi DRP dengan peringkat ketiga tertinggi. 
Tabel II Proporsi Tiap Kategori Drug-Related Problems

\begin{tabular}{lcc}
\hline Kategori DRPs & $\begin{array}{c}\text { Proporsi } \\
\text { Berdasarkan Pasien } \\
\mathbf{n}(\mathbf{\%})\end{array}$ & $\begin{array}{c}\text { Proporsi } \\
\text { Berdasarkan DRPs } \\
\mathbf{n}(\mathbf{\%})\end{array}$ \\
\hline Mengalami DRP(s) & $\mathbf{( N = 3 6 )}$ & $\mathbf{( N = 7 2 )}$ \\
Terapi obat yang tidak diperlukan & $29(80,56)$ & \\
Dosis obat terlalu rendah & $17(47,22)$ & $25(34,72)$ \\
Membutuhkan tambahan terapi obat & $15(41,67)$ & $18(25,00)$ \\
Dosis obat terlalu tinggi & $10(27,78)$ & $10(13,88)$ \\
Obat tidak efektif & $5(13,89)$ & $9(12,50)$ \\
Efek samping obat & $8(22,22)$ & $8(11,11)$ \\
Tidak mengalami DRP & $2(5,56)$ & $2(2,78)$ \\
\hline
\end{tabular}

*satu pasien dapat memiliki lebih dari satu DRPs

Terapi obat yang tidak diperlukan meliputi terapi tanpa indikasi yang jelas dan duplikasi terapi. Terapi tanpa indikasi yang jelas banyak terjadi pada penggunaan antibiotik, sedangkan duplikasi terapi banyak terjadi pada penggunaan obat gastrointestinal.

Terapi tanpa indikasi yang jelas pada penelitian ini umumnya terjadi pada penggunaan antibiotik pada bronkhitis akut yang mana penggunaan tersebut tidak dianjurkan kecuali apabila pasien disertai demam dan batuk yang menetap lebih dari enam hari karena gejala tersebut dicurigai melibatkan bakteri saluran napas seperti $S$. pneumonia dan $H$. Influenzae 20,21. Batuk yang menetap selama lebih dari sepuluh hari diduga melibatkan Mycobacterium pneumoniae sehingga penggunaan antibiotik disarankan ${ }^{22}$. Bronkitis akut umumnya disebabkan oleh virus yang umumnya tidak membutuhkan antibiotik, tetapi dapat diberikan terapi lini kedua menggunakan antibiotik seperti amoksisilin, kombinasi amoksisilinklavulanat, dan golongan makrolida apabila infeksi dicurigai melibatkan bakteri ${ }^{23}$. Antibiotik seperti ampisilin, amoksisilin, siprofloksasin, dan levofloksasin lebih direkomendasikan untuk diagnosis bronkitis 24. Namun demikian, masalah terapi tanpa indikasi pada penelitian ini umumnya merupakan diagnosis bronkitis yang tidak menunjukkan tanda-tanda infeksi seperti demam, batuk, dan leukositosis, tetapi tetap diberikan antibiotik.

Duplikasi terapi terjadi pada pasien yang menerima kombinasi metoklopramid dan ondansetron untuk diagnosis mual muntah padahal seharusnya cukup dengan salah satu obat saja. Suatu studi mengevaluasi efektivitas metoklopramid dibandingkan dengan ondansetron pada pengobatan gastroparesis pada pasien diabetes tipe 2 . Gastroparesis merupakan penundaan pengosongan lambung yang mengakibatkan mual dan muntah (vomiting). Hasil studi menunjukkan bahwa metoklopramid lebih disarankan untuk diberikan pada pasien diabetes tipe 2 dengan keluhan mual dan muntah dibandingkan ondansetron ${ }^{25}$. Namun demikian, apabila farmasis klinik tidak mampu menyelesaikan masalah duplikasi terapi secara langsung, maka solusi lain adalah dengan melakukan monitoring efek samping obat dan merekomendasi penyelesaiannya apabila efek samping benar terjadi. Meskipun tidak spesifik pada kasus mual-muntah atau diabetes tipe 2, tetapi hasil suatu studi menunjukkan bahwa monitoring terapi obat yang dilakukan oleh farmasis klinik pada setting rumah sakit (rawat inap) efektif dalam mendeteksi efek samping obat 26 sehingga farmasis klinik diharapkan tetap dapat meminimalkan luaran yang buruk dari masalah duplikasi terapi obat. 
Membutuhkan terapi obat tambahan pada penelitian ini salah satunya berupa dibutuhkannya tambahan terapi antihiperkolesterolemia baru untuk pasien dengan riwayat dislipidemia. Pasien-pasien tersebut umumnya memiliki nilai kolesterol total dan LDL yang jauh di atas nilai targetnya (kolesterol total $<200 \mathrm{mg} / \mathrm{dL}$, LDL $<100$ $\mathrm{mg} / \mathrm{dL}$ ), sedangkan pasien memiliki penyakit kardiovaskuler. Terapi yang direkomendasikan untuk pasien-pasien tersebut adalah golongan statin seperti simvastatin $^{27}$ karena statin mampu meningkatkan katabolisme dan menurunkan sintesis LDL sehingga dapat menurunkan kadar LDL dan kolesterol total. Penggunaan golongan statin yang memiliki potensi lebih tinggi (atorvastatin dan rosuvastatin) juga mampu menurunkan kadar trigliderida pada pasien dengan hipertrigliseridemia ${ }^{28}$.

Pada penelitian ini, DRP kategori membutuhkan terapi obat tambahan yang juga banyak terjadi adalah dibutuhkannya kombinasi insulin aksi singkat/cepat dan aksi sedang/panjang, yaitu ketika pasien diabetes tipe 2 dengan nilai $\mathrm{HbA1c}$, Gula Darah Sewaktu (GDS), Gula Darah Puasa (GDP), dan Gula Darah 2 Jam Post-Prandial (GD2JPP) jauh di atas nilai normalnya masing-masing ketika masuk rumah sakit diobati dengan insulin sliding scale dan antidiabetes oral (metformin, pioglitazon, glimepirid, atau akarbosa) secara bergantian. Namun, kadar gula darah pasien saat pasien keluar rumah sakit masih jauh di atas nilai normal, sedangkan pedoman terapi menjelaskan bahwa pasien diabetes tipe 2 dengan nilai $\mathrm{HbA1c}$ yang sangat tinggi $(\geq 9 \%)$ dapat langsung diberikan kombinasi tiga macam, kombinasi insulin basal (aksi sedang/panjang) dan bolus (aksi singkat/cepat), atau dengan insulin premixed apabila target terapi masih belum tercapai dengan kombinasi dua macam obat 29.

Obat tidak efektif terjadi pada penggunaan pansoprazole pada pasien diabetes tipe 2 dengan mual dan muntah. Pantoprazol bukan merupakan obat yang paling efektif untuk keluhan mual dan muntah pada pasien karena gejala mual muntah merupakan gejala komplikasi neuropati yaitu gastroparesis. Rekomendasi terapi yang sesuai untuk pasien diabetes tipe 2 dengan mual dan muntah akibat gastroparesis adalah pemberian metoklopramid, domperidon, atau eritromisin laktobionat. Metoklopramid adalah obat antiemetik golongan antagonis reseptor dopamin $\mathrm{D}_{2}$ yang disetujui oleh FDA sebagai pengobatan gastroparesis diabetik yang diberikan tidak lebih dari 12 minggu ${ }^{30}$.

Dosis obat terlalu rendah paling banyak terjadi pada insulin aspart (aksi cepat) dan antidiabetes oral. Masalah dosis obat yang terlalu rendah tersebut menyebabkan target GDS tidak tercapai yang menyebabkan penambahan dosis insulin atau antidiabetes. Sebuah artikel jurnal menyatakan bahwa insulin diberikan pada pasien diabetes dengan dosis awal 6 unit, tetapi dosis insulin bersifat individual, yaitu tergantung respon setiap individu terhadap insulin ${ }^{31}$. Dewitt dan Hirsch (2003) menyatakan bahwa dosis tambahan insulin 1-unit untuk setiap kenaikan $30 \mathrm{mg} / \mathrm{dL}$ kadar glukosa darah di atas target dapat diberikan pada pasien yang menerima insulin rapid acting untuk mencapai target glukosa darah yang dikehendaki ${ }^{27}$.

Efek samping obat aktual yang terjadi pada penelitian ini yaitu hipoglikemia. Pasien yang mengalami hipoglikemia hanya satu orang dengan manifestasi klinik hanya sebatas berupa lemas dan kadar glukosa darah 67 $\mathrm{mg} / \mathrm{dL}$ yang mengharuskan pemberian 2 flask infus dekstrosa $40 \%$ kepada pasien. Hipoglikemia umumnya terjadi akibat penggunaan obat antidiabetes insulin aspart secara sliding scale per 4 jam yang diberikan selama beberapa hari pasien dirawat inap. Insulin rapid acting diketahui memang berisiko lebih tinggi menyebabkan terjadinya hipoglikemia nokturnal dibanding pengobatan lainnya ${ }^{32}$.

Subkategori DRP membutuhkan obat yang lebih aman karena adanya suatu faktor risiko umumnya terjadi pada pasien dengan diare cair akut (DCA) yang diresepkan metoklopramid untuk pengatasan keluhan 
Tabel III Hubungan Antara DRP(s) dan Lama Rawat Inap

\begin{tabular}{|c|c|c|c|c|c|}
\hline Kategori DRPs & LOS $\geq 5$ hari & LOS $<5$ hari & $\begin{array}{c}\text { Proporsi } \\
\text { n (\%) } \\
(\mathrm{N}=36)\end{array}$ & Nilai $p$ & OR (IK 95\%) \\
\hline \multicolumn{6}{|c|}{ DRP(s) secara umum } \\
\hline Ya & 14 & 15 & $29(80,56)$ & $0,200^{\mathrm{b}}$ & $5,587(0,59-52,63)$ \\
\hline Tidak & 1 & 6 & $7(19,44)$ & & \\
\hline Kategori DRPs & LOS $\geq 5$ hari & LOS $<5$ hari & $\begin{array}{c}\text { Proporsi } \\
\text { n (\%) } \\
(\mathbf{N}=\mathbf{2 9 )}\end{array}$ & Nilai $p$ & OR (IK 95\%) \\
\hline \multicolumn{6}{|c|}{ Terapi obat yang tidak diperlukan } \\
\hline Ya & 9 & 5 & $14(48,28)$ & $0,016^{\mathrm{a}}$ & $7,20(1,35-38,33)$ \\
\hline Tidak & 3 & 12 & $15(51,72)$ & & \\
\hline \multicolumn{6}{|c|}{ Dosis obat terlalu rendah } \\
\hline Ya & 8 & 7 & $15(51,72)$ & $0,176^{\mathrm{a}}$ & $2,86(0,61-13,34)$ \\
\hline Tidak & 4 & 10 & $14(48,28)$ & & \\
\hline \multicolumn{6}{|c|}{ Tambahan terapi obat } \\
\hline Ya & 2 & 5 & $7(24,14)$ & $0,665^{b}$ & $0,48(0,08-3,03)$ \\
\hline Tidak & 10 & 12 & $22(75,86)$ & & \\
\hline \multicolumn{6}{|c|}{ Dosis obat terlalu tinggi } \\
\hline Ya & 3 & 2 & $5(17,24)$ & $0,622^{b}$ & $2,50(0,35-17,94)$ \\
\hline Tidak & 9 & 15 & $24(82,76)$ & & \\
\hline \multicolumn{6}{|c|}{ Obat tidak efektif } \\
\hline Ya & 2 & 5 & $7(24,14)$ & $0,665^{b}$ & $0,48(0,08-3,03)$ \\
\hline Tidak & 10 & 12 & $22(75,86)$ & & \\
\hline \multicolumn{6}{|c|}{ Efek samping obat } \\
\hline $\mathrm{Ya}$ & 1 & 0 & $1(3,44)$ & $0,561^{\mathrm{b}, \mathrm{c}}$ & $3,00(0,24-36,89)$ \\
\hline Tidak & 11 & 17 & $28(96,55)$ & & \\
\hline
\end{tabular}

$\mathrm{a}=$ Chi-Square test; $\mathrm{b}=$ Fisher's exact test; $\mathrm{c}=$ Haldane's correction

mual muntah pada pasien. Mual muntah pada DCA kurang tepat apabila diberikan metoklopramid karena metoklopramid dapat mempercepat pengosongan lambung yang akan memperparah kondisi DCA ${ }^{33}$ sehingga mual muntah pada DCA lebih baik direkomendasikan untuk diberikan ondansetron.

Dosis obat terlalu tinggi umumnya terjadi pada pasien bedah yang mendapat terapi seftriakson dengan durasi terlalu lama. Sebelum pasien dioperasi, pasien diberi antibiotik profilaksis seftriakson 1 gram IV. Namun demikian, pemberian seftriakson pascaoperasi masih dilanjutkan padahal antibiotik hanya direkomendasikan untuk terapi profilaksis dan penggunaan sesudah operasi dalam waktu 1 x 24 jam karena penggunaan antibiotik sesudah operasi dapat meningkatkan risiko resistensi antibiotik dan gangguan gastrointestinal jangka pendek akibat infeksi bakteri Clostridium difficile ${ }^{34}$.

\section{Hubungan DRPs dan LOS}

Lama rawat inap telah diketahui berpengaruh terhadap peningkatan beban biaya penyakit diabetes tipe $2{ }^{35}$. Peningkatan LOS pada pasien diabetes tipe 2 telah diketahui disebabkan oleh komorbid seperti gagal jantung kongestif, dementia, tukak peptik, gangguan hati, dan gangguan ginjal ${ }^{36}$. Lama rawat inap pasien diabetes tipe 2 juga dapat meningkat akibat usia 37,38, tindakan operasi kegawatan ${ }^{39}$, infeksi nosokomial ${ }^{40}$, 
Tabel IV Obat yang Berhubungan dengan Drug-Related Problems

\begin{tabular}{lc}
\hline & Proporsi \\
Obat & $\mathbf{n} \mathbf{( \% )}$ \\
& $\mathbf{( N = 7 2 )}$ \\
\hline Antidiabetes & $18(25)$ \\
Insulin rapid acting & $6(8,33)$ \\
Insulin long acting & $4(5,56)$ \\
Metformin & $4(5,56)$ \\
Pioglitazon & $4(5,56)$ \\
Antibiotik & $15(20,83)$ \\
Seftriakson & $9(12,50)$ \\
Metronidazol & $2(2,78)$ \\
Lain-lain & $4(5,56)$ \\
Obat gastrointestinal & $15(20,83)$ \\
Pantoprazol & $6(8,33)$ \\
Ondansetron & $3(4,17)$ \\
Ulsafat & $2(2,78)$ \\
Metoklopramid & $2(2,78)$ \\
Domperidon & $1(1,39)$ \\
Ranitidin & $1(1,39)$ \\
Antihipertensi & $2(2,78)$ \\
Amlodipin & $1(1,39)$ \\
Kandesartan & $1(1,39)$ \\
\hline
\end{tabular}

metode pembayaran rumah sakit, dan efikasi terapi ${ }^{41}$, tetapi masih belum diketahui apakah DRPs mempengaruhi LOS sehingga penelitian ini mencoba menghubungkan antara DRPs dan LOS.

Hubungan antara DRPs dan LOS dapat dilihat pada Tabel III. Data pada tabel tersebut sedikit berbeda dengan data pada Tabel II karena pada Tabel II, satu pasien dapat memiliki lebih dari satu DRPs, sedangkan pada Tabel III, data telah disesuaikan. Berdasarkan Tabel III, hasil penelitian menunjukkan bahwa secara umum, DRPs tidak berhubungan dengan LOS berdasarkan semua nilai $p$ yang selalu $>0,05$. Namun demikian, terdapat satu jenis DRP yang secara signifikan berhubungan dengan LOS, yaitu terapi obat yang tidak diperlukan $(\mathrm{p}=0,016)$, meskipun kekuatan hubungan tidak begitu besar (OR 7,20 [IK95\% 1,35-38,33]). Length of stay (LOS) pada penelitian ini dikategori menjadi dua yaitu LOS $<5$ hari dan $\geq 5$ hari.
Hal tersebut berdasarkan pertimbangan bahwa rerata rerata LOS adalah $4,11 \pm 1,82$ hari dan nilai tengah (median) LOS adalah 4 hari. Lama rawat inap pasien dikelompokkan dalam kelompok $\leq 4$ hari (atau LOS $<5$ hari) dan kelompok $>4$ hari (atau LOS $\geq$ 5 hari).

Penelusuran hubungan antara DRPs secara umum dengan LOS berdasarkan semua pasien (36 pasien) yang menjadi subjek penelitian ini, tetapi penelusuran hubungan antara tiap kategori DRPs dengan LOS hanya berdasarkan pada pasien yang mengalami DRPs (29 pasien). Hal tersebut disebabkan oleh pertimbangan peneliti bahwa penelusuran hubungan antara DRPs dengan LOS akan lebih baik apabila dilakukan pada subkelompok yang lebih spesifik yaitu pada perihal ini adalah subkelompok pasien yang mengalami setidaknya satu DRP selama dirawat inap. Hasil penelitian ini belum dapat dibandingkan dengan studi lain karena 
Tabel Va. Proporsi Obat atau Golongan Obat pada Tiap Kategori Drug-Related Problems

\begin{tabular}{|c|c|}
\hline Kategori DRPs* & $\begin{array}{c}\text { Proporsi } \\
\text { n (\%) } \\
(\mathrm{N}=72)\end{array}$ \\
\hline \multicolumn{2}{|l|}{ 1. Terapi obat yang tidak diperlukan } \\
\hline a. Terapi tanpa indikasi yang jelas & $20(27,78)$ \\
\hline Antibiotik & $5(6,94)$ \\
\hline Vitamin & $4(5,56)$ \\
\hline Benzodiazepin & $2(2,78)$ \\
\hline NSAIDs & $2(2,78)$ \\
\hline Pantoprazol & $1(1,39)$ \\
\hline Simvastatin & $1(1,39)$ \\
\hline Lain-lain & $5(6,94)$ \\
\hline b. Duplikasi terapi & $5(6,94)$ \\
\hline Obat gastrointestinal & $5(6,94)$ \\
\hline \multicolumn{2}{|l|}{ 2. Membutuhkan tambahan terapi obat } \\
\hline a. Butuh tambahan terapi & $5(6,94)$ \\
\hline Antidislipidemia & $2(2,78)$ \\
\hline Obat jantung & $1(1,39)$ \\
\hline Antihipertensi & $1(1,39)$ \\
\hline Obat batuk & $1(1,39)$ \\
\hline b. Butuh kombinasi obat & $5(6,94)$ \\
\hline Insulin & $5(6,94)$ \\
\hline \multicolumn{2}{|l|}{ 3. Obat tidak efektif } \\
\hline a. Obat tidak efektif untuk kondisi pasien & $4(5,56)$ \\
\hline Obat gastrointestinal & $2(2,78)$ \\
\hline Metil prednisolon & $1(1,39)$ \\
\hline Azitromisin & $1(1,39)$ \\
\hline \multirow{3}{*}{$\begin{array}{l}\text { b. Terdapat obat yang lebih efektif } \\
\text { Pantoprazol } \\
\text { Metronidazol dan seftriakson }\end{array}$} & $2(2,78)$ \\
\hline & $1(1,39)$ \\
\hline & $1(1,39)$ \\
\hline \multirow{3}{*}{$\begin{array}{l}\text { c. Kontraindikasi obat } \\
\text { Seftriakson } \\
\text { Ketorolak }\end{array}$} & $2(2,78)$ \\
\hline & $1(1,39)$ \\
\hline & $1(1,39)$ \\
\hline
\end{tabular}

peneliti masih belum berhasil menemukan studi lain yang juga menelusuri hubungan antara DRPs dengan LOS.

Meskipun penelitian ini dilakukan secara prospektif dengan harapan agar data yang diperoleh dapat lebih valid, tetapi penelitian ini masih memiliki keterbatasan yaitu sumber data lain dalam penelitian berasal dari rekam medik pasien yang mana catatan rekam medik dalam beberapa kasus tidak lengkap sehingga kurang mendukung hasil analisis DRPs yang terjadi pada pasien.

\section{KESIMPULAN}

Drug-Related Problems (DRPs) pasien diabetes tipe 2 rawat inap pada penelitian ini adalah sebesar $80,56 \%$ dengan rincian proporsi DRPs berdasarkan jumlah kejadian DRPs yaitu terapi obat yang tidak diperlukan terjadi sebesar $34,72 \%$; dosis obat terlalu rendah $25 \%$; membutuhkan tambahan terapi obat $13,38 \%$; dosis obat terlalu tinggi $12,5 \%$; obat tidak efektif $11,11 \%$; dan efek samping obat 2,78\%; serta terlihat ada kecenderungan hubungan yang lemah antara DRP terapi obat 
Tabel V. Proporsi Obat atau Golongan Obat pada Tiap Kategori Drug-Related Problems

\begin{tabular}{|c|c|c|}
\hline \multicolumn{2}{|r|}{ Kategori DRPs* } & $\begin{array}{c}\text { Proporsi } \\
\text { n }(\%) \\
(\mathrm{N}=72) \\
\end{array}$ \\
\hline 4. & Dosis obat terlalu rendah & \\
\hline \multirow[t]{4}{*}{ a. } & Dosis obat terlalu rendah & $16(22,22)$ \\
\hline & Antidiabetes & $9(12,50)$ \\
\hline & Insulin & $4(5,56)$ \\
\hline & Antihipertensi & $3(4,17)$ \\
\hline \multirow[t]{3}{*}{ b. } & Durasi terlalu pendek & $2(2,78)$ \\
\hline & Parasetamol & $1(1,39)$ \\
\hline & Ranitidin & $1(1,39)$ \\
\hline 5. & Efek samping obat & \\
\hline \multirow[t]{2}{*}{ a. } & Efek samping obat & $1(1,39)$ \\
\hline & Insulin aspart & $1(1,39)$ \\
\hline \multirow[t]{2}{*}{ b. } & Perlu obat yang lebih aman & $1(1,39)$ \\
\hline & Metoklopramid & $1(1,39)$ \\
\hline \multirow[t]{6}{*}{6.} & Dosis obat terlalu tinggi & \\
\hline & Durasi terlalu panjang & $9(12,50)$ \\
\hline & Antibiotik & $6(8,33)$ \\
\hline & Ketolorak & $1(1,39)$ \\
\hline & Diazepam & $1(1,39)$ \\
\hline & Difenhidramin & $1(1,39)$ \\
\hline
\end{tabular}

yang tidak diperlukan dengan LOS pada pasien diabetes tipe 2 rawat inap.

\section{DAFTAR PUSTAKA}

1. World Health Organization. Global Report on Diabetes.; 2016.

2. International Diabetes Foundation. IDF DIABETES ATLAS Eighth Edition.; 2017.

3. Badan Penelitian dan Pengembangan Kesehatan. Riset Kesehatan Dasar 2013.; 2013.

4. Muka T, Imo D, Jaspers L, et al. The global impact of non-communicable diseases on healthcare spending and national income: a systematic review. Eur J Epidemiol. 2015;30(4):251-277.

5. Seuring T, Archangelidi O, Suhrcke M. The Economic Costs of Type 2 Diabetes: A Global Systematic Review. Pharmacoeconomics. 2015;33(8):811-831.

6. Ogbonna BO, Ezenduka CC, Opara CA, Ahara LG. Drug therapy problems in patients with type 2 diabetes. Int J Innov Res Dev. 2014;3(1):494-502.
7. van Roozendaal BW, Krass I. Development of an evidence-based checklist for the detection of drug related problems in type 2 diabetes. Pharm World Sci. 2009;31(5):580-595.

8. Inamdar SZ, Kulkarni RV. Drug related problems in elderly patients with type 2 diabetes mellitus. J Diabetol. 2018;1(1):112.

9. Cramer JA, Benedict A, Muszbek N, Keskinaslan A, Khan ZM. The significance of compliance and persistence in the treatment of diabetes, hypertension and dyslipidaemia: a review. Int J Clin Pract. 2008;62(1):76-87.

10. Ernst FR, Grizzle AJA. Drug-related morbidity and mortality: updating the cost-of-illness model. J Am Pharm Assoc. 2001;41(2):192-199.

11. Pfister B, Jonsson J, Gustafsson M. Drug-related problems and medication reviews among old people with dementia. BMC Pharmacol Toxicol. 2017;18:52. 
12. Chiampas TD, Kim H, Badowski M. Evaluation of the occurrence and type of antiretroviral and opportunistic infection medication errors within the inpatient setting. Pharm Pract (Granada). 2015;13(1):512.

13. Martinez-Ramirez D, Giugni JC, Little CS, et al. Missing Dosages and Neuroleptic Usage May Prolong Length of Stay in Hospitalized Parkinson' s Disease Patients. PLoS One. 2015;10(4):e0124356.

14. Dedefo MG, Mitike AH, Angamo MT. Incidence and determinants of medication errors and adverse drug events among hospitalized children in West Ethiopia. BMC Pediatr. 2016;16:81.

15. Lemeshow S, Hosmer Jr. DW, Klar J, Lwanga SK. Adequacy of Sample Size in Health Studies. Chichester: John Wiley \& Sons; 1990.

16. Cipolle R, Strand LM, Morley P. Pharmaceutical Care Practice. New York: McGraw-Hill; 1998.

17. Zazuli Z, Rohaya A, Adnyana IK. Drug-related problems in Type 2 diabetic patients with hypertension in Cimahi, West Java, Indonesia: A prospective study. Int J Green Pharm. 2017;11(2):S298-S304.

18. Mogre V, Salifu ZS, Abedandi R. Prevalence, components and associated demographic and lifestyle factors of the metabolic syndrome in type 2 diabetes mellitus. J Diabetes Metab Disord. 2014;13(1):1-7.

19. Iglay K, Hannachi H, Howie PJ, et al. Prevalence and co-prevalence of comorbidities among patients with type 2 diabetes mellitus. Curr Med Res Opin. 2016;32(7):1243-1252.

20. MacKay D. Treatment of acute bronchitis in adults without underlying lung disease. $J$ Gen Intern Med. 1996;11(9):557-562.

21. O'Brien KL, Dowell SF, Schwartz B, Marcy M, Phillips WR, Gerber MA. Cough Illness/Bronchitis-Principles of Judicious Use of Antimicrobial Agents.
Pediatrics. 1998;101(Supplement 1):178181.

22. Direktorat Bina Farmasi Komunitas dan Klinik. Pharmaceutical Care Untuk Penyakit Infeksi Saluran Pernapasan.; 2005.

23. Blackford MG, Glover ML, Reed MD. Lower Respiratory Tract Infections. In: Pharmacotherapy: A Pathophysiologic Approach, 8th Edition. ; 2011:1845-1865.

24. DiPiro JT. Antimicrobial Regimen Selection. In: Pharmacotherapy Handbook Ninth Edition. ; 2015:313-322.

25. Snape WJ, Battle WM, Schwartz SS, Braunstein SN, Goldstein HA, Alavi A. Metoclopramide to Treat Gastroparesis due to Diabetes Mellitus: A DoubleBlind, Controlled Trial. Ann Intern Med. 1982;96(4):444-446.

26. Emerson A, Martin RM, Tomlin M, Mann RD. Prospective cohort study of adverse events monitored by hospital pharmacists. Pharmacoepidemiol Drug Saf. 2001;10:95-103.

27. DeWitt DE, Hirsch IB. Outpatient Insulin Therapy in Type 1 and Type 2 Diabetes Mellitus. J Am Med Assoc. 2003;289(17):2254-2264.

28. Schwinghammer TL. Dyslipidemia. In: Pharmacotherapy Handbook Ninth Edition. ; 2015:65-74.

29. American Diabetes Association. Diabetes Care in the Hospital. Diabetes Care. 2017;40(Suppl.):120-127.

30. Lee A, Kuo B. Metoclopramide in the treatment of diabetic gastroparesis. Expert Rev Endocrinol Metab. 2011;5(5):653-662.

31. Bogun $M$, Inzucchi SE. Inpatient Management of Diabetes and Hyperglycemia. Clin Ther. 2013;35(5):724-733.

32. Pedersen-Bjergaard U, Kristensen PL, Beck-Nielsen $\mathrm{H}$, et al. Effect of insulin analogues on risk of severe hypoglycaemia in patients with type 1 diabetes prone to recurrent severe hypoglycaemia (HypoAna trial): a prospective, randomised, open-label, 
blinded-endpoint crossover trial. Lancet Diabetes Endocrinol. 2014;2(7):553-561.

33. Fink S, Lange R, McCallum R. Effect of metoclopramide on normal and delayed gastric emptying in gastroesophageal reflux patients. Dig Dis Sci. 2015;15(17):1-9.

36. Enomoto LM, Shrestha DP, Rosenthal MB, Hollenbeak CS, Gabbay RA. Risk factors associated with 30-day readmission and length of stay in patients with type 2 diabetes. J Diabetes Complications. 2017;31(1):122-127.

37. Chen JY, Ma Q, Chen H, Yermilov I. New Bundled World: Quality of Care and Readmission in Diabetes Patients. J Diabetes Sci Technol. 2012;6(3):563-571.

38. Raval AD, Zhou S, Wei W, Bhattacharjee S, Miao R, Sambamoorthi U. 30-Day Readmission Among Elderly Medicare Beneficiaries with Type 2 Diabetes. Popul Health Manag.
1983;28(12):1057-1061.

34. World Health Organization. Global Guidelines on the Prevention of Surgical Site Infection.; 2016.

35. Rubin DJ. Hospital Readmission of Patients with Diabetes. Curr Diab Rep. 2015;18(4):256-264.

39. Dungan KM. The Effect of Diabetes on Hospital Readmissions. J Diabetes Sci Technol. 2012;6(5):1045-1052.

40. Dryden M, Baguneid M, Eckmann C, et al. Pathophysiology and burden of infection in patients with diabetes mellitus and peripheral vascular disease: focus on skin and soft-tissue infections. Clin Microbiol Infect. 2015;21(S2):27-32.

41. Huang D, Xie L, Qiu Y. Analysis of Factors Affecting the Length of Hospital Stay for Patients with Diabetes. Exp Clin Endocrinol Diabetes. 2016;124(1):5-10. 